\title{
DETERMINAN AUDITOR SWITCHING SECARA VOLUNTARY
}

\author{
Nana Umdiana \\ Universitas Serang Raya \\ nanaumdianaunsera@gmail.com
}

\author{
Siska \\ Universitas Serang Raya \\ ka.sis36@hotmail.com
}

\begin{abstract}
Abstrak: Determinan Auditor Switching secara Voluntary. Penelitian ini bertujuan untuk menganalisis pengaruh pergantian manajemen, Qualified opinion (Opini Wajar Degan Pengecualian) dan Ukuran perusahaan yang berpengaruh terhadap Auditor Switching (Pergantian Auditor) secara voluntary (sukarela) pada perusahaan Pertambangan yang terdaftar di Bursa Efek Indonesia tahun periode 2015-2018. Jenis penelitian ini adalah penelitian kausal asosiatif dan Jenis data yang digunakan adalah data sekunder. Analisis data menggunakan SPSS versi 25 .Populasi dalam penelitian ini adalah perusahaan-perusahaan sub pertambangan yang terdaftar di Bursa Efek Indonesia tahun 2015 - 2018. Namun untuk beberapa variabel dibutuhkan data tahun sebelumnya. Metode pengumpulan data yang digunakan dalam penelitian ini adalah purposive sampling, yaitu berdasarkan kriteria yang telah ditentukan. Sebanyak 6 perusahaan yang digunakan sebagai sampel perusahaan. Data dianalisis dengan statistik deskriptif dan regresi logistic. Berdasarkan hasil dari analisis menunjukkan bahwa pergantian manajemen, qualifiedopini, dan ukuran perusahaan tidak berpengaruh terhadap auditorswitching secara voluntary
\end{abstract}

Kata Kunci : pergantian Auditor, pergantian manajemen, Sukarela

Abstract: Determinants Of Voluntary Auditor Switching. This research has a purpose to analize the effect of management changes, qualified opinion and size of clien to auditor switching voluntary in mining companies listed in the Indonesia Stock Exchange in 2015-2018.The type of this research was associativecausal and the type of data used is secondary data. Data analysis uses SPSS version 25. The population in this research are sub-mining companies listed on the Indonesia Stock Exchange in 2015 - 2018. However, for some variables the previous year's data is needed. Data collection method used in this research was purposive sampling, which is based on predetermined criteria. A total of 6 companies were used as sample companies. Data were analyzed using descriptive statistical analysis and logistic regression.The results of analize showed that management changes, qualified opinion, and size of clien do not affect to auditor switching voluntary

Keywords: Auditor switching, countary, management changes, Voluntary

\section{PENDAHULUAN}

Auditing memberikan nilai tambah bagi laporan keuangan perusahaan dalam menambah integritas laporan keuangan sehingga laporan tersebut bisa dipercaya untuk kepentingan pihak luar entitas seperti pemegang saham, kreditor, pemerintah dan lain-lain. Sehingga laporan keuangan yang disajikan harus sesuai dengan fakta agar informasi yang diberikan andal dan tidak menyesatkan para pemakai laporan keuangan tersebut. Karena pengguna laporan keuangan hanya dapat mengandalkan informasi di laporan 


\section{Nominal: Barometer Riset Akuntansi dan Manajemen}

P-ISSN: 2303-2065 E-ISSN: 2502-5430

Volume 10 No 1 (2021)

keuangan ketika laporan keuangan tersebut telah diaudit oleh seorang auditor independen. Salah satu cara dalam meningkatkan independensi auditor yaitu dengan melakukan pergantian auditor atau KAP untuk menjaga independensi dan kepercayaan publik.

Pemerintah mengeluarkan aturan yang mengatur rotasi auditor atau perputaran auditor yang harus dilakukan oleh suatu Perusahaan. Tahun 2015, pemerintah mengeluarkan PP No. 20/2015 tentang Praktik Akuntan Publik. Dalam PP No. 20/2015 pasal 11 ayat (1) dijelaskan bahwa KAP tidak lagi dibatasi dalam melakukan audit atas suatu perusahaan. Pembatasan hanya berlaku bagi akuntan publik, yaitu selama 5 tahun buku berturut-turut.

Akuntan publik diwajibkan melakukan cooling-off selama 2 tahun setelah memberikan jasa audit atas informasi keuangan terhadap suatu perusahaan selama 5 tahun buku berturut-turut. setelah cooling-off selesai akuntan publik diperkenankan kembali untuk memberikan jasa auditnya pada perusahaan yang sama. Pergantian auditor bisa disebabkan oleh kewajiban rotasi yang diatur oleh Pemerintah (mandatory) atau pergantian secara sukarela (voluntary), Pergantian sukarela (voluntary) lebih memfokuskan perhatiannya pada sisi klien. Pergantian sukarela (voluntary) terjadi karena adanya ketidaksesuaian antara auditor dengan klien. Sedangkan pergantian wajib (mandatory) terjadi karena adanya peraturan yang membatasi antara klien dengan auditor yang disebut dengan audit tenure (masa perikatan). AuditorSwitching dilakukan secara voluntary akan menimbulkan berbagai persepsi bagi pengguna laporan keuangan. Oleh karena itu perlu di teliti faktor penyebab perusahaan tersebut melakukan auditorswitching secara voluntary. Penelitian mengenai auditorswitching sebenarnya sudah banyak yang dilakukan, namun menggunakan faktor determinan dan sektor yang berbeda sehingga menghasilkan hasil yang berbeda juga .

Faktor pertama yang mempengaruhi auditorswitching secara voluntary adalah pergantian manajemen. Pergantian manajemen dalam perusahaan sering kali diikuti oleh perubahan kebijakan dalam perusahaan maka Perusahaan akan mencari KAP yang selaras dengan kebijakan dan pelaporan akuntansinya.

Faktor lain yang mempengaruhi auditorswitching secara voluntary yaitu opini wajar dengan pengecualian (Qualifed Opinion) dari auditor, perusahaan menginginkan laporan keuangannya mendapat opini wajar tanpa pengecualian 


\section{Nominal: Barometer Riset Akuntansi dan Manajemen}

P-ISSN: 2303-2065 E-ISSN: 2502-5430

Volume 10 No 1 (2021)

(unqualified opinion) dari KAP. Jika auditor tidak dapat memberikan opini wajar tanpa pengecualian (tidak dengan harapan perusahaan), perusahaan akan berpindah KAP yang mungkin dapat memberikan opini sesuai dengan yang diharapkan perusahaan.

Faktor selanjutnya, ukuran perusahaan juga dapat menjadi salah satu faktor yang

\section{KAJIAN LITERATUR}

Teori Agensi

Teori agensi berpendapat bahwa antara pemilik dan manajemen memiliki kepentingan sendiri. Dimana pemilik menginginkan pengembalian investasi dengan optimal, sementara manajemen memiliki tujuan mendapatkan bonus dan tambahan kompensasi dari kinerjanya. Dengan adanya kepentingan yang berbeda antara pemilik modal dan pengelola akan menyebabkan ketidakseimbangan informasi yang diberikan, untuk bisa menyeimbangkan informasi yang diberikan kepada publik makan perusahaan harus menggunakan jasa Kantor Akuntan Publik. Akuntan Publik memiliki fungsi sebagai penyeimbang dan penengah untuk meminimalkan biaya agensi yang akan timbul dari dua kepentingan tersebut.

Perusahaan melakukan pergantian Auditor untuk memisahkan kepemilikan menyebabkan perusahaan melakukan auditor switching. Pada saat ukuran perusahaan meningkat, perusahaan yang besar membutuhkan auditor dengan reputasi yang lebih baik untuk meningkatkan kepercayaan shareholders. Rasionalisasinya reputasi auditor harus sesuai dengan ukuran perusahaan dan jenis layanan yang dibutuhkan.

dan pengendalian perusahaan antara prinsipal dan agen (Jensen \& Meckling, 1976). Jensen dan Meckling (1976) berpendapat masalah agensi disebabkan oleh adanya konflik kepentingan dan asimetris informasi antara pemegang saham dan manajemen. Konflik ini terjadi karena kemungkinan agen tidak selalu berbuat sesuai dengan kepentingan principal, sehingga memicu biaya keagenan (agency $\cos t$ ).

Auditor switching dapat dilakukan oleh perusahaan dengan cara hanya mengganti auditornya saja atau mengganti Kantor Akuntan Publiknya (KAP). Penyebab adanya pergantian auditor dapat terjadi dari dua belah pihak baik dari perusahaan/klien atau dari auditornya sendiri. Perusahaan melakukan pergantian auditor memiliki banyak sebab dan alasan antara lain bisa disebabkan oleh pergantian manajemen, ukuran perusahaan yang semakin 


\section{Nominal: Barometer Riset Akuntansi dan Manajemen}

P-ISSN: 2303-2065 E-ISSN: 2502-5430

Volume 10 No 1 (2021)

berkembang, financial distress, auditor atau auditor switching dengan kompleksitas perusahaan dan lain-lain. dikeluarkannya Keputusan Menteri Pergantian auditor disebabkan oleh auditornya itu sendiri memiliki penyebab antara lain besarnya fee yang tidak sesuai dengan jasa yang diberikan, atau alasan tertentu yang mengakibatkan auditor mundur dari perjanjian atau kontrak (Fitriani, 2014).

Febrianto (2009) menyatakan menghindari risiko litegasi yang melekat pada klien adalah salah satu alasan auditor mengundurkan diri dari tugasnya. Alasan lain seorang Auditor mengundurkan diri dari tugasnya di sebut dengan kebijakan konservatif, kebijakan ini timbul dikarenakan klien memaksakan metode akuntansi yang mereka sukai namun ditentang oleh auditor. Pergantian auditor secara sukarela dari perusahaan klien adalah fokus utama dari penelitian ini, pergantian auditor ada dua jenis yang bisa dilakukan oleh perusahaan yaitu pergantian secara sukarela dan pergantian auditor karena kewajiban. Pergantian auditor karena kewajiban ini timbul karena aturan atau paksaan yang mengharuskan melakukan pergantian auditor aturan ini dibuat oleh pemerintah untuk melakukan rotasi audit.

Indonesia adalah salah satu negara yang telah mengatur kewajiban rotasi

Keuangan Republik Indonesia Nomor 359/KMK.06/2003 pasal 2 tentang "Jasa Akuntan Publik" (perubahan atas Keputusan Menteri Keuangan Nomor 423/KMK.06/2002) peraturan ini menyatakan "bahwa pemberian jasa audit umum atas laporan keuangan dari suatu entitas dapat dilakukan oleh Kantor Akuntan Publik (KAP) paling lama untuk 5 (lima) tahun buku berturut-turut dan oleh seorang akuntan publik paling lama untuk 3 (tiga) tahun buku berturut-turut".

Peraturan tersebut kemudian diperbaharui dengan dikeluarkannya Peraturan Menteri Keuangan Republik Indonesia Nomor 17/PMK.01/2008 tentang "Jasa Akuntan Publik" yaitu "Pemberian jasa audit umum menjadi 6 (enam) tahun berturut-turut oleh kantor akuntan dan 3 (tiga) tahun berturut-turut oleh akuntan publik kepada satu klien yang sama (pasal 3 ayat 1), akuntan publik (AP) dan kantor akuntan (KAP) boleh menerima kembali penugasan setelah satu tahun buku tidak memberikan jasa audit kepada klien tersebut (pasal 3 ayat 2 dan 3)".

Peraturan tersebut juga kembali mengalami revisi dengan dikeluarkannya Peraturan Pemerintah Republik Indonesia Nomor 20 tahun 2015 mengenai 


\section{Nominal: Barometer Riset Akuntansi dan Manajemen}

P-ISSN: 2303-2065 E-ISSN: 2502-5430

Volume 10 No 1 (2021)

pembatasan jasa audit, dimana pemberian jasa audit terhadap suatu entitas oleh Akuntan Publik dibatasi paling lama untuk 5 (lima) tahun buku berturut-turut (pasal 10 ayat 1$)$.

Otoritas Jasa Keuangan mengeluarkan POJK Nomor 13 Tahun 2017 tentang Penggunaan Jasa Akuntan Publik dan Kantor Akuntan Publik dalam Kegiatan Jasa Keuangan. Hal ini dibuat untuk memperketat pengawasan terhadap akuntan publik dalam melakukan audit. Peraturan tersebut berisikan bahwa setiap penggunaan jasa audit dari kantor akuntan publik paling lama 3 (tiga) tahun buku berturut-turut. Sedangkan pembatasan penggunaan jasa dari KAP tergantung pada hasil evaluasi Komite Audit. Dan OJK mewajibkan setiap perusahaan memilih Kantor Akuntan Publik (KAP) yang sudah masuk dalam daftar OJK.

Rotasi atau pergantian manajemen dalam suatu perusahaan adalah hal yang lumrah dilakukan oleh setiap perusahaan baik perusahaan kecil ataupun perusahaan besar, pergantian manajemen ini merupakan strategi bisnis demi kemajuan dan perkembangan perusahaan, pergantian ini bisa dilakukan karena kemauan sendiri dari manajemen yang ada karena sudah terlalu lama dana jenuh bisa juga karena sudah pensiun, pergantian manajemen juga bisa disebabkan keputusan yang dilakukan oleh para pemegang saham di dalam rapat umum pemegang saham, biasanya dalam rups pergantian manajemen lebih menekankan ke dalam strategi pengembangan perusahaan pada dasarnya pemegang saham ingin memperoleh laba maksimal. Dampak dari pergantian manajemen yang baru tentu saja akan memiliki kebijakan baru pula, baik dalam pemilihan metode akuntansi yang digunakan serta pemilihan kantor akuntan publik yang akan digunakan sesuai dengan kepentingan dan strategi mereka, hal ini sesuai dengan teori agensi bahwa setiap individu bertindak atas dan untuk kepentingan mereka sendiri,

Nazri et al.. (2012) berpendapat bahwa para pemangku kepentingan mengidentifikasi kelemahan perusahaan situasi utama dari lemahnya manajemen yang ada, sebagai bentuk dukungan mereka terhadap perusahaan maka mereka mengusulkan perubahan manajemen. Teori agensi berpendapat karena manajemen atau agen dipilih oleh mereka para pemegang saham maka manajemen harus bertindak berdasarkan keinginan dan kepentingan mereka. Dengan adanya pemilihan atau pergantian manajemen baru maka perikatan atau kontra antara klien dan auditor harus dilakukan perubahan, bisa juga memicu 
Nominal: Barometer Riset Akuntansi dan Manajemen

P-ISSN: 2303-2065 E-ISSN: 2502-5430

Volume 10 No 1 (2021)

perubahan auditor (Williams, 1988 dalam

Nazri et al., 2012).

Opini Audit - Wajar Dengan Pengecualian (Qualified Opinion). Opini audit merupakan pernyataan pendapat yang diberikan oleh auditor dalam menilai kewajaran perjanjian laporan keuangan perusahaan yang diauditnya. Dalam Standar Profesional Akuntan Publik (2001) dijelaskan bahwa tujuan audit atas laporan keuangan oleh auditor independen adalah untuk menyatakan pendapat tentang kewajaran mengenai semua hal yang material, posisi keuangan, hasil usaha, perubahan ekuitas, dan arus kas sesuai dengan akuntansi yang berlaku umum di Indonesia.

Pendapat wajar dengan pengecualian ini hanya diberikan jika secara keseluruhan laporan keuangan yang disajikan adalah wajar, tetapi ada beberapa unsur yang dikecualikan, yang pengecualiannya tidak mempengaruhi kewajaran laporan keuangan secara keseluruhan. pada teori agensi, perusahaan akan melakukan pergantian auditor jika auditor tidak memberikan opini sesuai dengan keinginan mereka.

Auditor mengklasifikasikan besar kecilnya suatu usaha yang berhubungan dengan finansial adalah dari ukuran perusahaan yang di yang dapat dilihat dari beberapa jenis rasio, diantaranya dari total penjualan, jumlah aktiva dan lain-lain. Brigham \& Houston, (2001) menyatakan bahwa ukuran perusahaan dapat dihitung dengan mencari rata-rata antara penjualan bersih tahun berjalan dengan beberapa tahun sebelumnya, indikator yang lain untuk menilai ukuran perusahaan adalah dengan menggunakan nilai total aset. Dalam penelitian ini peneliti menggunakan total aset sebagai variabel atau dasar perhitungan, total aset digunakan karena total aset lebih stabil dan representatif dalam mengukur besar kecilnya perusahaan di bandingan dengan proksi yang lain. Ukuran perusahaan diukur dengan logaritma natural dari total aktiva digunakan rumus :

Ukuran Perusahaan $=$ Ln Total Aset

\section{METODE PENELITIAN}

Penelitian ini merupakan penelitian causal bertujuan menguji hubungan sebab akibat antara variable yang diteliti. penelitian ini menggunakan pendekatan kuantitatif dan asosiatif. Penelitian asosiatif menggambarkan dan menguji hipotesis hubungan dua variabel atau lebih (Sugiyono, 2017, p. 20) . Pendekatan kuantitatif dapat diartikan sebagai penelitian yang berlandaskan pada filsafat positivisme (Sugiyono, 2017) 


\section{Nominal: Barometer Riset Akuntansi dan Manajemen}

P-ISSN: 2303-2065 E-ISSN: 2502-5430

Volume 10 No 1 (2021)

Variabel yang digunakan dalam penelitian ini yaitu, Auditor Switching, Pergantian Manajemen, Opini Audit, dan Ukuran Perusahaan. Skala pengukuran yang digunakan untuk variable auditor switching adalah dummy dimana peneliti memberikan nilai tertentu, dalam hal ini peneliti memberikan nilai 0 untuk perusahaan yang tidak melakukan auditor switching secara voluntary dan memberikan nilai 1 untuk perusahaan yang melakukan auditor switching secara voluntary. Pergantian manajemen juga menggunakan pengukuran secara dummy dimana peneliti memebrikan nilai 1 untuk perusahaan yang melakukan pergantian manajemen dan nilai 0 untuk perusahaan yang tidak melakukan pergantian manajemen. Begitu juga dengan opini wajar dengan pengajuan pengukuran menggunakan dummy. Untuk variabel ukuran perusahaan atau ukuran klien peneliti menggunakan proksi logaritma dari total aset.

Dalam penelitian ini penulis mengambil populasi perusahaan sektor Pertambangan yang terdaftar di Bursa Efek Indonesia (BEI) sebanyak 41 perusahaan. Teknik pengambilan sampel dalam penelitian ini menggunakan proposive sampling, teknik pengambilan sampel purposive sampling yaitu sampel diambil berdasarkan kriteria tertentu sesuai dengan tujuan penelitian yang dianggap mewakili penelitian sebagai berikut :

Proses mengolah dan menganalisis data dari penelitian ini peneliti menggunakan alat bantu statistik yaitu SPSS (Statistical Product and Service Solustion) Versi 25, dan teknik analisis data ini menggunakan regresi logistik. Analisis logistik dalam model regresi logistik sebagai berikut :

ASwich $=\alpha+b 1 M C H+$ b2Qopini $+b 3 \operatorname{LnT} A+e$

Keterangan :

Aswich : Pergantian Auditor ( Auditor switching)

$\alpha \quad$ : Konstanta

MCH : Pergantian Manajemen ( Management Changes )

Qopini : Opini wajar dengan pengecualian (Qualified opinion)

LnTA : Ukuran Perusahaan

b1-b5 : Koefisien regresi

Pengujian Hipotesis dengan tingkat signifikansi 5\%. Dengan kriteria penerimaan atau penolakan akan di dasarkan pada nilai sig ( $p$-value) dengan alpha sebesar 5\% dimana p-value yang $<5 \%$ menunjukkan bahwa hipotesis diterima atau terdapat pengaruh yang signifikan dari variabel bebas terhadap variabel terikat 


\section{HASIL PENELITIAN DAN}

\section{PEMBAHASAN}

Untuk melihat nilai minimum, maksimum, mean dan standar deviasi dalam penelitian ini menggunakan statistik deskriptif, adapun hasil dari uji statistik deskriptif adalah sebagai berikut :

Tabel 1 Hasil Uji Statistik Deskriptif

\begin{tabular}{lcccrr}
\hline & N & Min & Max & Mean & \multicolumn{2}{l}{$\begin{array}{l}\text { Std. } \\
\text { Dev. }\end{array}$} \\
\hline $\begin{array}{l}\text { Pergantian } \\
\text { Manajemen }\end{array}$ & 24 & 0 & 1 & .21 & .415 \\
$\begin{array}{l}\text { Qualifield } \\
\text { Opinion }\end{array}$ & 24 & 0 & 1 & .04 & .204 \\
$\begin{array}{l}\text { Ukuran } \\
\text { Perusahaan }\end{array}$ & 24 & 18.7 & 26.2 & 22.592 & 24.537 \\
$\begin{array}{l}\text { Auditor } \\
\text { Switching }\end{array}$ & 24 & 0 & 1 & .38 & .495 \\
$\begin{array}{l}\text { Valid N } \\
\text { (listwise) }\end{array}$ & 24 & & & & \\
\hline
\end{tabular}

Sumber : Output SPSS 25,2019

\section{Uji Kelayakan Model Regresi Logistik}

Tabel 2 Overall Model Vit

Iteration $\quad-2$ Log likelihood

\begin{tabular}{lc}
\hline Step 0 & 31.755 \\
Step 1 & 28.780 \\
\hline & Sumber : Output SPSS 25, 2019
\end{tabular}

Pada tabel 2 menunjukkan Iteration History 0 , nilai -2 LogLikelihood pertama menunjukkan angka sebesar 31,755 . setelah variabel bebas dimasukkan pada model regresi, maka nilai -2 Log Likelihood pada tabel diatas Iteration History 1 menunjukkan angka sebesar 28,780. Berdasarkan hasil pengujian tersebut, terjadi penurunan nilai -2 LogLikelihood antara awal dan akhir yaitu sebesar 2,975. Penurunan nilai -2 LogLikelihood ini dapat diartikan bahwa penambahan variabel bebas kedalam model dapat memperbaiki model fit serta menunjukkan model regresi yang lebih baik.

Tabel 3 Hosmer and Lemeshow Test

\begin{tabular}{llll}
\hline Step & Chi-square & Df & Sig. \\
\hline 1 & 7.089 & 8 & .527 \\
\hline
\end{tabular}

Berdasarkan tabel tersebut pengujian menunjukkan nilai Chi-square sebesar 7,089 dengan nilai signifikansi adalah sebesar 0,527. Nilai signifikansi yang diperoleh tersebut diatas 0,05 yang berarti model mampu memprediksi nilai observasinya sehingga model ini dapat digunakan untuk analisis selanjutnya karena model tersebut mampu memprediksi hasil observasinya.

Tabel 4 Negelkerke R square

\begin{tabular}{llll}
\hline Step & $\begin{array}{l}-2 \text { Log } \\
\text { likelihood }\end{array}$ & $\begin{array}{l}\text { Cox \& } \\
\text { Snell R } \\
\text { Square }\end{array}$ & $\begin{array}{l}\text { Nagelker } \\
\text { ke R } \\
\text { Square }\end{array}$ \\
\hline 1 & $28.780^{\mathrm{a}}$ & .117 & .159 \\
\hline
\end{tabular}

Nilai koefisien determinasi di dalam model regresi logistik dapat ditunjukkan dari nilai Nagelkerke $R$ Square.Nilai Nagelkerke R Square adalah sebesar 0,159 yang berarti variabilitas variabel dependen auditor switching secara voluntary yang dapat dijelaskan oleh variabel independen Perubahan manajemen, Qualified opinion dan ukuran perusahaan adalah sebesar $15,9 \%$, sedangkan sisanya sebesar $84,1 \%$ dijelaskan oleh variabel-variabel lain di luar model penelitian. 
Tabel 5 Uji Multikolinieritas

\begin{tabular}{|c|c|c|}
\hline \multirow[t]{2}{*}{ Model } & \multicolumn{2}{|c|}{$\begin{array}{l}\text { Collinearity } \\
\text { Statistics }\end{array}$} \\
\hline & Tolerance & VIF \\
\hline (Constant) & & \\
\hline Pergantian & .988 & 1.012 \\
\hline Manajemen & & \\
\hline Qualifield Opinion & .959 & 1.043 \\
\hline Ukuran Perusahaan & .970 & 1.031 \\
\hline
\end{tabular}

Berdasarkan tabel coeficients nilai tolance variabel Pergantian Manajemen, Qualified opinion dan ukuran perusahaan berkisar antara 0,959 sampai 0,988 atau lebih besar dari 0,10. Hasil perhitungan nilai tolance tersebut menunjukkan tidak ada variabel independen yang memiliki nilai tolerance kurang dari 0,10 yang berarti tidak adanya korelasi antar variabel independen. Hasil perhitungan nilai Variance Inflation Factor (VIF) juga menunjukkan hal yang sama tidak ada satu variabel independen yang memiliki nilai VIF lebih dari 10 sehingga dapat disimpulkan bahwa tidak ada multikolonieritas antar variabel independen dalam model regresi.

Kekuatan prediksi dari model regresi untuk memprediksi kemungkinan perusahaan melakukan perpindahan KAP secara sukarela (Voluntary) adalah sebesar $11,1 \%$. Hal ini menunjukkan bahwa dengan menggunakan model regresi yang digunakan, terdapat sebanyak 1 perusahaan $(11,1 \%)$ yang diprediksi akan melakukan perpindahan Kantor Akuntan Publik dari total 9 perusahaan yang melakukan perpindahan Kantor Akuntan Publik. Kekuatan prediksi model perusahaan yang tidak melakukan perpindahan KAP adalah sebesar $100 \%$ yang berarti bahwa dengan model regresi yang digunakan ada sebanyak 15 perusahaan (100\%) yang diprediksi tidak melakukan perpindahan KAP dari total 15 perusahaan yang tidak melakukan perpindahan KAP. . Dapat disimpulkan bahwa kekuatan prediksi dari model regresi sebesar $66,7 \%$.

\section{Analisis Regresi Logistik}

Hasil Pengujian terhadap regresi menghasilkan model sebagai berikut :

$$
\begin{gathered}
\text { ASwich }=1,763-0,943 \text { MCH }+5,859 \text { Qopini } \\
-0,099 \operatorname{LnTA}+e
\end{gathered}
$$

\section{Hasil Uji Hipotesis}

\section{Pengujian Regresi Logistik Secara Parsial}

Menjawab hipotesis mengenai pengaruh independen terhadap dependen secara parsial, dapat dilihat dari nilai signifikan yang ada pada hasil output SPSS pada tabel Variables in the Equation pada kolom sig dibandingkan dengan tingkat nilai aplha 0,05. Hasil Pengujian menunjukkan signifikansi sebesar 0,440 lebih besar dari 0,05 (5\%). Maka dapat disimpulkan bahwa hipotesis pertama tidak berhasil di dukung (ditolak) yaitu variabel Pergantian Manajemen, penelitian ini gagal membuktikan adanya pengaruh Pergantian 
Nominal: Barometer Riset Akuntansi dan Manajemen

P-ISSN: 2303-2065 E-ISSN: 2502-5430

Volume 10 No 1 (2021)

Manajemen terhadap auditorswitching secara voluntary. Hasil pengujian menunjukkan sebesarnya signifikansi 0,665 lebih besar dari 0,05 (5\%). Maka dapat disimpulkan hipotesis kedua tidak berhasil di dukung (ditolak) yaitu variabel Opini Wajar Dengan Pengecualian. penelitian ini gagal membuktikan adanya pengaruh opini wajar dengan pengecualian (Qualified opinin) terhadap auditor switching secara voluntary. Berdasarkan hasil pengujian dapat diketahui bahwa diperoleh nilai wald sebesar $0,288 \quad$ (sig. $0,592 \quad$ ). Nilai signifikansi 0,592 lebih besar dari 0,05 (5\%). Maka dapat disimpulkan bahwa hipotesis ketiga gagal (ditolak) membuktikan bahwa Ukuran perusahaan tidak memiliki pengaruh terhadap pergantian auditor (auditor switching).

\section{PEMBAHASAN}

\section{Pengaruh Pergantian Manajemen}

Terhadap Auditor Switching secara

\section{Voluntary}

Berdasarkan hasil pengujian secara statistik nilai signifikasi dari pergantian manajemen terhadap auditor switching sebesar 0,440 dengan demikian penelitian gagal membuktikan adanya pengaruh diantar dua variabel tersebut. Dengan demikian dapat di simpulkan bahwa setiap pergantian manajemen belum tentu akan dilakukan pergantian auditor atau pergantian kantor akuntan publik. Hal ini juga menunjukkan bahwa manajemen baru masih bisa menggunakan KAP yang lama tentukan dengan melakukan negosiasi ulang agar kedua belah pihak dapat menyelaraskan sistem kerjanya. Hasil Penelitian tidak mendukung hasil penelitian sebelumnya yang di lakukan Puspa dan Yadnyana (2015), Wijayani dan Januarti (2011). Meskipun demikian hasil penelitian ini mendukung penelitian yang dilakukan Yanti (2015), Damayanti dan Sudarma (2007).

\section{Pengaruh Opini Wajar Dengan Pengecualian \\ (QualifiedOpinion)}

Terhadap Auditor Switching secara Voluntary

Pada pengujian hipotesis kedua juga gagal membuktikan opini wajar tanpa pengecualian memiliki pengaruh yang signifikan terhadap auditor switching ini dapat dilihat dari nilai signifikasi yang melebihi 0,05 yaitu sebesar 0,665 . Peneliti menduga gagalnya opini wajar tanpa pengecualian memiliki pengaruh terhadap auditor switching dikarenakan sampel yang digunakan tidak mewakili populasi yang ada. Karena pada umumnya setiap perusahaan sudah memperoleh opini wajar tanpa pengecualian. Dengan 


\section{Nominal: Barometer Riset Akuntansi dan Manajemen}

P-ISSN: 2303-2065 E-ISSN: 2502-5430

Volume 10 No 1 (2021)

memperolehnya opini tersebut perusahaan akan cenderung untuk mempertahankan auditor tersebut, mereka tidak mau mengambil risiko dengan mengganti auditor yang sudah ada karena dikhawatirkan dengan pergantian akan menurunkan kualitas pelaporan keuangan perusahaan dan akan menyebabkan sentimen pasar yang negatif.

Pada teori agensi jika manajemen tidak memperoleh opini wajar tanpa pengecualian pihak manajemen cenderung akan mengganti auditor, sebab manajemen dan pemilik perusahaan akan selalu menginginkan opini wajar tanpa pengecualian karena itu adalah tujuan utama dari manajemen agar nilai perusahaan bisa menarik para investor.

Namun penelitian ini gagal membuktikan karena sampel yang tidak mewakili dari 41 perusahaan yang terdaftar di BEI pada sektor Pertambangan hanya ada 1 perusahaan yang mendapat opini wajar dengan pengecualian yaitu PT Bumi Resource di tahun 2015 . Penelitian ini tidak mendukung hasil penelitian yang di lakukan Dwiyani dan Sabeni (2014).

\section{Pengaruh Ukuran Perusahaan}

Terhadap AuditorSwitching secara Voluntary

Penelitian ini gagal membuktikan adanya pengaruh antara ukuran perusahaan klien terhadap auditor switching dengan taraf signifikansi $(\rho)$ sebesar 0,592 , lebih besar dari $\alpha=5 \%(0,05)$. Hasil yang ada menunjukkan ukuran perusahaan tidak berpengaruh terhadap auditor switching.

Hasil Penelitian tidak mendukung hasil penelitian sebelumnya yang di lakukan Dwiyani dan Sabeni (2014), Yanti (2015). Meskipun demikian hasil penelitian ini mendukung penelitian yang dilakukan Pradipta dan Septiani (2014).

Perusahaan yang besar cenderung akan memilih Kantor Akuntan Publik yang besar pula karena ini akan menggambarkan kesesuaian antara perusahaan dan Kantor Akuntan Publiknya, biasanya perusahaanperusahaan besar akan memilihi kantor akuntan publik yang bonafid seperti kantor akuntan publik big four, sedangkan untuk perusahaan-perusahaan yang memiliki sekali kecil lebih cenderung memilih KAP non Big 4 sehingga tidak ada kecenderungan untuk melakukan auditor switching. Ukuran perusahaan akan mencerminkan aktivitas operasi dari perusahaan tersebut perusahaan besar pada umumnya memiliki aktivitas lebih kompleks dibandingkan dengan perusahaan yang ukuran sedang atau kecil. Hasil pengujian membuktikan bahwa perusahaan besar atau kecil tidak selalu pasti akan melakukan auditor switching, mereka 
Nominal: Barometer Riset Akuntansi dan Manajemen

P-ISSN: 2303-2065 E-ISSN: 2502-5430

Volume 10 No 1 (2021)

melakukan auditor switching hanya

berdasarkan kebutuhan saja.

\section{SIMPULAN DAN SARAN}

Pengaruh Pergantian Manajemen terhadap auditor switching secara voluntary menunjukkan bahwa secara statistik tidak terdapat pengaruh. Maka dapat disimpulkan bahwa hipotesis pertama tidak berhasil di dukung (ditolak) yaitu Pergantian Manajemen tidak berpengaruh terhadap auditor switching secara voluntary. Hasil pengujian dapat di simpulkan bahwa setiap pergantian manajemen belum tentu akan dilakukan pergantian auditor atau pergantian kantor akuntan publik. Hal ini juga menunjukkan bahwa manajemen baru masih bisa menggunakan KAP yang lama tentukan dengan melakukan negosiasi ulang agar kedua belah pihak dapat menyelaraskan sistem kerjanya. Pengaruh opini wajar dengan pengecualian terhadap auditor switching secara voluntary menunjukkan bahwa secara statistik tidak terdapat pengaruh. Maka dapat disimpulkan bahwa hipotesis kedua tidak berhasil di dukung (ditolak) yaitu pengaruh opini wajar dengan pengecualian tidak berpengaruh terhadap auditor switching secara voluntary. jika manajer memperoleh opini yang tidak sesuai, maka dapat menyebabkan dilakukannya pergantian

manajemen. Sehingga manajemen akan berusaha memperoleh opini audit yang diinginkan karena salah satu tujuan manajemen perusahaan yaitu untuk memperoleh opini audit wajar tanpa pengecualian dari auditor. Namun penelitian ini gagal membuktikan karena sampel yang tidak mewakili dari 41 perusahaan yang terdaftar di BEI pada sektor Pertambangan hanya ada 1 perusahaan yang mendapat opini wajar dengan pengecualian yaitu PT Bumi Resource di tahun 2015. Pengaruh ukuran perusahaan terhadap auditor switching secara voluntary menunjukkan bahwa secara statistik tidak terdapat pengaruh. Dengan ini dapat disimpulkan bahwa hipotesis ketiga gagal (ditolak) membuktikan bahwa Ukuran perusahaan tidak memiliki pengaruh terhadap pergantian auditor (auditor switching) secara voluntary. Hasil pengujian menunjukkan Perusahaan-perusahaan besar yang menggunakan KAP skala besar cenderung tidak akan mengganti auditornya yang menggambarkan kesesuaian KAP dengan ukuran perusahaan kliennya. Sebagian besar dari perusahaanperusahaan yang mempunyai skala kecil menggunakan KAP non Big 4 sehingga tidak ada kecenderungan untuk melakukan auditor switching. 


\section{DAFTAR PUSTAKA}

Brigham, F., \& Houston, J. (2001). DasarDasar Manajemen Keuangan. Edisi 8. Jakarta: Salemba Empat.

Damayanti, S., \& Sudarma, M. (2007). Faktor-Faktor yang Mempengaruhi Perusahaan Berpindah Kantor Akuntan Publik. Pontianak: Simposium Nasional 11.

Dwiyanti, R. M., \& Sabeni, A. (2014). Faktor-Faktor yang Mempengaruhi Auditor Switching secara Voluntary. Diponegoro Journal of Accounting, 716-723.

Fitriani, N. A. (2014). Analisis FaktorFaktor Yang Mempengaruhi Voluntary Auditor Switching Di Perusahaan Manufaktur Indonesia (Studi Empiris pada Perusahaan Manufaktur yang Terdaftar di Bursa Efek Indonesia (BEI) Tahun 2008-2012). SKRIPSI : Universitas Diponegoro Semarang.

Jensen, \& Meckling. (1976). The Theory of The Firm: Manajerial Behaviour, Agency Cost, and Ownership Structure. Journal of Financial and Economics, 3, 305-360.

Nazri, Smith, M., \& Ismail, Z. (2012). Factors Influencing Auditor
Change: Evidence. Asian Review of Accounting, 3, 222-240.

Pradipta, R. P., \& Septiani, A. (2014). Faktor-Faktor Yang Mempengaruhi Perusahaan Manufaktur Terdaftar Di Bei Melakukan Pergantian Auditor Secara Voluntary. Diponegoro Journal of Accounting, 793-802.

Puspa, N. M., \& Yadnyana, K. (2015). Pengaruh Audit Delay, Opini Audit , Reputasi Auditor dan Pergantian Manajemen pada Voluntary Auditor Switching. E-Jurnal Akuntansi Universitas Udayana, 10(1), 214-228.

Sugiyono. (2017). Metode Penelitian Kuantitatif, Kualitatif, dan $R \& D$. Bandung: Alfabeta, CV.

Wijayani, E., \& Januarti, I. (2011). Analisis Faktor-faktor yang mempengaruhi perusahaan di Indonesia melakukan Auditor Switching. Aceh: SNA XIV 2011.

Yanti, M. (2015). Analisis Faktor-Faktor Yang Mempengaruhi Pergantian Auditoe (Studi Pada Perusahaan Real Estate Tahun 2009-2013). Jakarta: Universitas Trisakti. 